\title{
Change in size and abundance of Caribbean spiny lobsters Panulirus argus in a marine reserve in the Florida Keys National Marine Sanctuary, USA
}

\author{
Carrollyn Cox*, John H. Hunt \\ Florida Fish and Wildlife Conservation Commission, Fish and Wildlife Research Institute, South Florida Regional \\ Laboratory, 2796 Overseas Highway, Suite 119, Marathon, Florida 33050, USA
}

\begin{abstract}
Spiny lobster size and abundance have been monitored in the Western Sambo Ecological Reserve since its designation in 1997 as a fully protected marine reserve in the Florida Keys National Marine Sanctuary. Surveys were conducted in July (during the closed fishing season) and September (following the first month of the fishing season) in both the reserve and in an adjacent exploited area. The reserve comprises 3000 ha extending from the shoreline to the $18 \mathrm{~m}$ depth contour past the spur-and-groove forereef. Western Sambo contains several distinctly different habitats, which lobsters use during different life stages. It appears that a residential population of spiny lobsters is becoming established within the reserve. The mean size of legal lobsters and the frequency of occurrence of very large lobsters, especially males, have increased steadily since full protection was implemented in 1997. The largest legal-sized lobsters were found on offshore patch reefs. Lobster abundance varied significantly by site, fishing season, and habitat. The overall abundance of spiny lobsters in the reserve varied without trend among years, but the abundance of legal-sized lobsters during the closed season increased significantly in the reserve relative to the exploited area.
\end{abstract}

KEY WORDS: Spiny lobster · Marine reserves · MPAs · Fishery management · Population dynamics $\cdot$ Panulirus argus

Resale or republication not permitted without written consent of the publisher

\section{INTRODUCTION}

Spiny lobsters support one of Florida's most economically important commercial fisheries (Harper 1995) and a large recreational fishery (Bertelsen \& Hunt 1991, Sharp et al. 2004). Spiny lobster stocks in Florida are highly exploited (Harper \& Muller 2001); the fishery removes a large portion of the available stock each year (Muller et al. 1997) and relies heavily on recently matured individuals that are just over the legal-size limit of $76.2 \mathrm{~mm}$ carapace length (CL) (Powers \& Sutherland 1989, Beaver 2000). Approximately $90 \%$ of Florida landings come from the Florida Keys (Hunt 1994, Harper 1995, Muller et al. 1997).

Marine reserves have potential benefits in spiny lobster fishery management. Depending upon their location and size, reserves may protect juveniles until they mature and enter the fishery or they may protect or enhance existing spawning stock (Childress 1997, Sladek Nowlis \& Roberts 1999). Historically, spiny lobsters were not considered to be good candidates for protection in reserves because of their migratory nature (Bohnsack 1996). However, despite their mobility, some spiny lobster populations have been found to benefit from protected areas. MacDiarmid \& Breen (1993) documented a substantial increase in the size and abundance of Jasus edwardsii within the first few years of establishment of a fishery reserve in northeastern New Zealand. Recently, Kelly et al. (2000) reported increased spiny lobster biomass in 4 marine reserves in New Zealand. Similar observations have been made for Panulirus argus in Dry Tortugas National Park (Davis 1977, Warner et al. 1977, Bertelsen et al. 2000). In addition, it has been sug- 
gested that even temporary protection of highly mobile species in reserves can result in enhanced population fecundity (Sladek Nowlis \& Roberts 1999).

The effectiveness of a fishery reserve for lobsters depends upon several factors. The size of the reserve relative to the home range of the lobster is important (MacDiarmid 1991, MacDiarmid et al. 1991). Lobsters can move up to $5 \mathrm{~km}$ away from their daytime dens in a single night to search for food (Herrnkind et al. 1975) and as much as $200 \mathrm{~km}$ in less than a year (Davis \& Dodrill 1980, 1989). The shape (i.e. perimeter-to-area ratio) of the reserve is also important (Schonewald-Cox \& Bayless 1986, Acosta 2002). It is critically important that the appropriate habitats, including shelter, foraging, and reproductive habitats, are protected (Cox et al. 1997, Acosta 2001). Additionally, the effectiveness of the reserve in providing recruits to the metapopulation depends upon the reserve location and whether the local population protected is a larval source or sink (Lipcuis et al. 2001).

Marine reserves can enhance the spawning potential of spiny lobsters in 2 ways. An increase in the abundance of reproductively mature lobsters should lead to an increase in population fecundity. An increase in the mean size of existing spawning stock will also lead to an increase in the reproductive output of the population because clutch size is dependent on both female and male size (see MacDiarmid \& Butler 1999, Bertelsen \& Cox 2001). Bertelsen \& Cox (2001) found that the average clutch size of females in a lobster sanctuary was 2.6 times larger than that of females in the adjacent exploited area; clutch size varies exponentially with female CL. Large females are unlikely to mate with small males, but when they do, clutches fertilized by small males are significantly smaller than those fertilized by large males (MacDiarmid \& Butler 1999). Davis (1975) postulated reproductive 'senescence' of very large female lobsters in Dry Tortugas National Park, which at the time was open only to recreational harvest. However, the lack of reproduction most probably resulted from a paucity of potential mates because most of the large males had been removed by the fishery (Bertelsen \& Cox 2001).

On July 1, 1997, the Florida Keys National Marine Sanctuary (FKNMS) established a series of 23 marine reserves along the Florida Reef Tract. The largest of these, Western Sambo Ecological Reserve (WES), contains the greatest habitat diversity in the Lower Florida Keys (US Department of Commerce [DOC] 1996). All human consumptive activities are prohibited in the reserve to provide a natural area in which marine life can spawn, mature, and permanently reside (DOC 1996). We have monitored spiny lobster size and abundance in WES since July 1997 to determine if it is an effective reserve for spiny lobsters (information available at: http://www.fknms.nos.noaa.gov/research_ monitoring/2001_sci_rept.pdf). Our sampling protocol was designed to test the hypothesis that lobsters in the reserve will become larger and more abundant than those found in an adjacent, exploited reference area.

\section{MATERIALS AND METHODS}

Study sites. WES comprises 3000 ha extending from the shoreline to the 18-m depth contour offshore from the spur-and-groove forereef (Fig. 1). WES contains distinctly different habitats that lobsters use during different life stages. Therefore, we stratified our sampling by habitat.

Habitat strata included the following: forereef, backreef, offshore patch reef, and nearshore patch reef. On the forereef, lobster dens were found on the top and sides of spurs as well as under them. Backreef dens were found under isolated coral heads, under rubble ledges, and in seagrass blow-outs. Offshore patch reefs contained diverse hard and soft coral cover with dens under the numerous coral heads and along the patch edges. Nearshore, dens were found in and under the small patch reefs and isolated coral heads surrounded by seagrass.
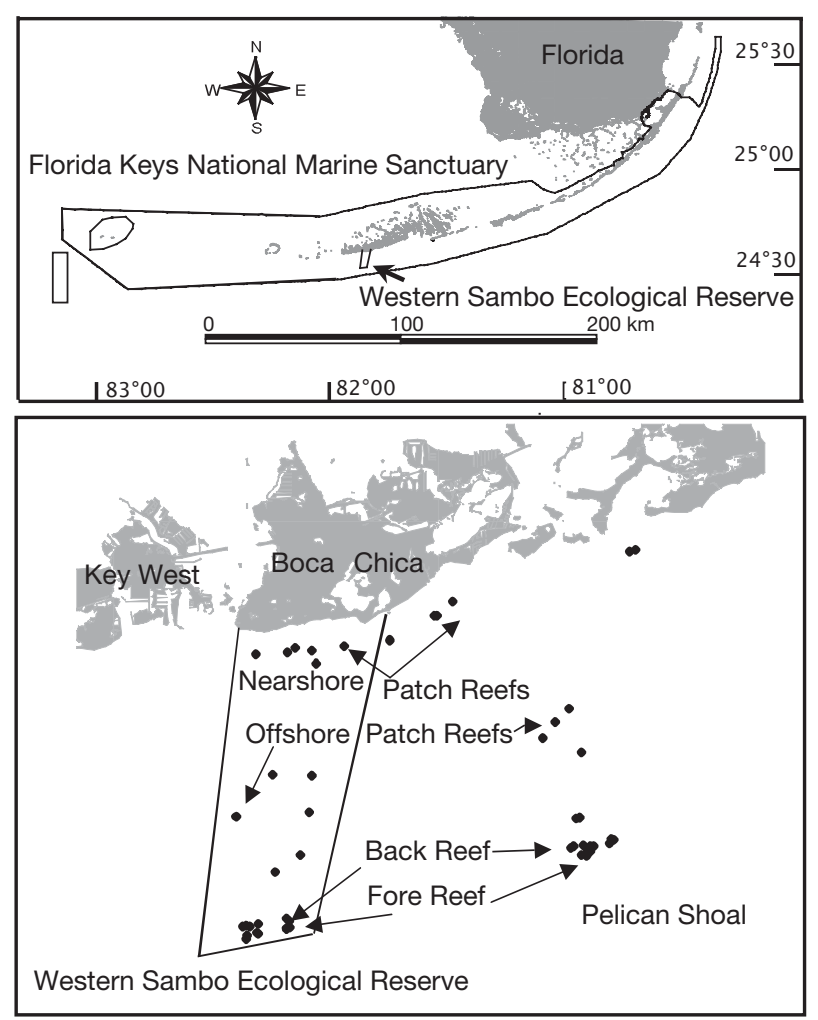

Fig. 1. Florida Keys showing the Florida Keys National Marine Sanctuary boundary and the study sites, Western Sambo Ecological Reserve (WES) and Pelican Shoal (PLS) 
Every year from 1997 through 2001, we conducted lobster surveys within each stratum in July (the end of the closed fishing season) and in September (following the first month of the fishing season). Similar sampling was conducted in the adjacent exploited area surrounding Pelican Shoal (PLS) (Fig. 1). The sampling schedule was chosen to fall near the end of the reproductive season to minimize differences in lobster abundance related to migration following the reproductive period.

Survey methods. We conducted 3 surveys within each habitat during both the closed and open fishing season every year. Anchoring locations were chosen haphazardly, depending on weather, water visibility, tide, current, and other boat traffic. Swimming route was also haphazard, depending on current, visibility, diver, etc. We attempted to space surveys across the forereef and backreef so that we would not recapture the same lobsters on different surveys.

Surveys consisted of 60 min timed searches for spiny lobsters. Capture time was not included as part of the 60 min search time. Additionally, time was kept only when divers were over suitable lobster habitat. When it was necessary to traverse a large area of sand or seagrass, the clock was turned off. We chose to use timed surveys which yield relative abundance estimates (number of lobsters per unit time) rather than transect surveys which yield density estimates (number of lobsters per unit area) because lobsters are gregarious and their distribution is patchy. There is a high probability of finding zero lobsters in a randomly placed transect, even when it is placed in high quality lobster habitat where lobsters are abundant. With timed searches, we sample more lobsters on each survey, and obtain more data relating to size, sex ratio and reproductive condition. Additionally, with timed surveys, more time can be spent sampling instead of placing and retrieving transect tapes (Schmitt et al. 2002). A core group of 4 biologists conducted sampling and trained additional staff each year. To ensure consistency, divers who were not proficient in the sampling method functioned in a support diver capacity only.

At the time of capture, we numbered each lobster and recorded its sex and den depth. All captured lobsters were brought to the boat where size (mm CL), molt stage, and reproductive status of females (presence/absence of spermatophores, ripe ovaries, and eggs) were recorded. Lobsters were returned alive to the area of capture. Lobsters that eluded capture were always counted and included in abundance estimates. Sex and estimated size of these lobsters were recorded whenever possible, and those values were used in subsequent analyses.

Data analysis. Sex ratio: Data from the 3 surveys at each site were combined to increase the sample size of males and females for calculation of sex ratio. Sex ratios at the 2 sites were calculated as no. of females/ no. of males and were compared by habitat and fishing season by using log-transformed values to meet analysis of variance (ANOVA) assumptions. Post hoc multiple comparisons were made using the StudentNeuman-Keuls procedure (SNK). Lobsters of undetermined sex were excluded from sex ratio analyses.

Size: Lobster sizes at the 2 sites were compared by habitat, year, and season using ANOVA. Problems with heterogeneous variance were not resolved by transforming the data, but ANOVA is robust to heterogeneous variance (Zar 1984), so untransformed data were analyzed. Post hoc multiple comparisons were made using Tamhane's T2 test which does not assume homogeneous variance among groups (SPSS 1999). Lobsters of undetermined size were excluded from analyses.

Abundance: In instances when it is more important to know whether a population is increasing or decreasing than it is to know its absolute size, relative abundance-number per unit time-is an appropriate measure (Odum 1971). We estimated relative abundance of lobsters as no. of lobsters $\mathrm{h}^{-1}$. For the 9 surveys in which search time did not equal $60 \mathrm{~min}$, abundance was extrapolated. Abundances at the 2 sites were compared by year, fishing season, and habitat using ANOVA. Again, variance homogeneity was not achieved by transformation for either total or legalsized lobster abundance, so untransformed data were analyzed, and post hoc multiple comparisons were made using Tamhane's T2 test.

The abundance of lobsters in WES, as percentage of the number of lobsters sampled in WES and PLS combined, was calculated and regressed on year to determine if the abundance of lobsters in WES was increasing or decreasing relative to that in PLS. This calculation was made using data for legal-sized lobsters captured during the closed season. Only legalsized lobsters were included in this analysis to reduce variance in the data caused by episodic recruitment of small lobsters and because protection from harvest should be most evident in fishable (legal-sized) lobsters. This calculation enabled us to compare relative abundance of lobsters between the 2 sites directly, independent of the natural yearly variation.

\section{RESULTS}

\section{Summary statistics}

We completed 229 of 240 scheduled surveys from 1997 to 2001, and counted a total of 3569 lobsters at WES and 2366 lobsters at PLS. We were not able to sample nearshore patch reefs during the 1998 open fishing season following Hurricane Georges and Trop- 


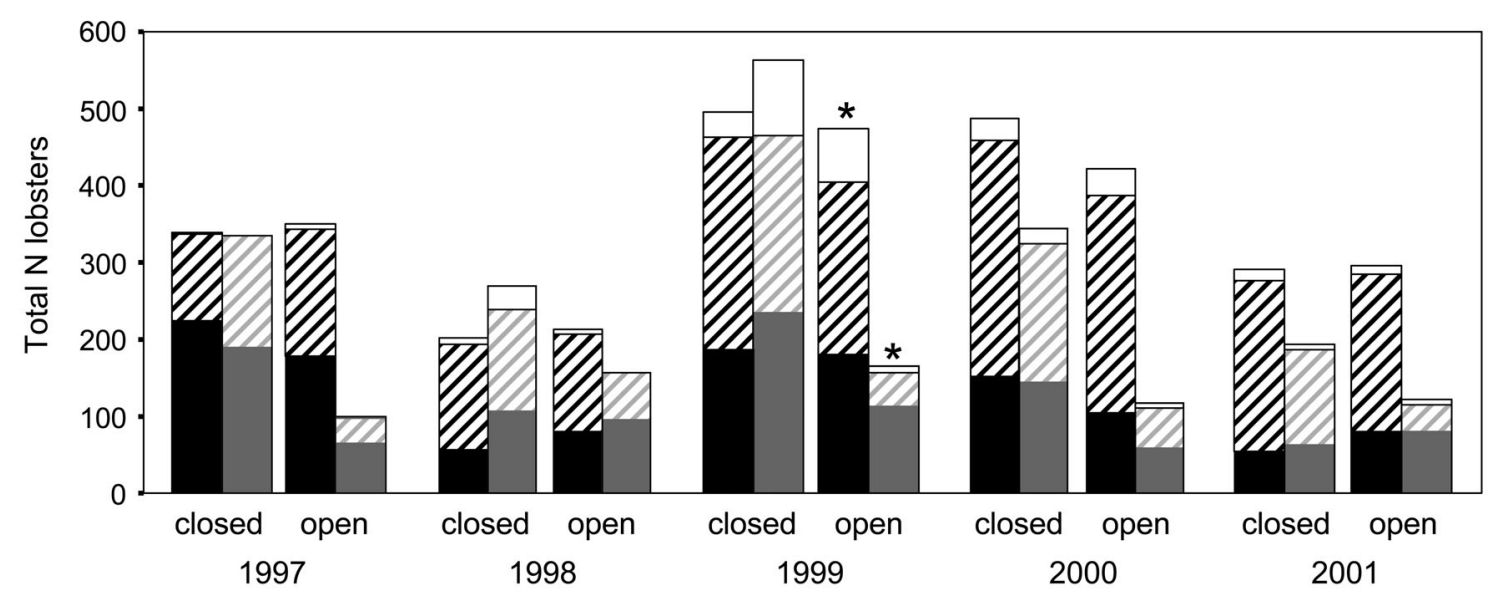

Fig. 2. Panulirus argus. Total number (N) of lobsters of known size counted in Western Sambo Ecological Reserve (WES) and Pelican Shoal (PLS) 1997 to 2001 by fishing season (habitats combined). Bars represent the sums of 3 searches (each 60 min). Left bar of each pair: WES; right bar of each pair: PLS; solid bars (bottom of stack): sublegal-sized lobsters; hatched bars (middle of stack): legal-sized lobsters; white bars (top of stack): lobsters of undetermined size; *: data extrapolated (data from missing replicates have been estimated to equal the mean of completed replicates to make totals comparable)

ical Storm Mitch. During the 1999 open fishing season, several replicate samples on the patch reefs were not completed (WES 2 nearshore patches; PLS 1 offshore patch, 2 nearshore patches) because of poor visibility. Lobsters were most numerous in 1999 and least numerous in 1998 (Fig. 2, Table 1). Similar numbers of lobsters were counted in both the protected and exploited areas during July 1997, 1998, and 1999 (Fig. 2). Each year, the effects of fishing were evident by the reduction in the total number of lobsters counted in the exploited area during the open fishing season. By July 2000 , the total number of lobsters counted in the protected and unprotected areas was no longer equalmore lobsters were found in the reserve (Fig. 2).

The proportion of legal and sublegal lobsters in WES was similar during the closed and open fishing seasons. At PLS, the percentage of legal-sized lobsters during the open fishing season decreased (Fig. 2). For the closed fishing seasons from 1997 to 2001 combined, data show that $61 \%$ of lobsters at WES were of legal size and $53 \%$ of those at PLS were of legal size. For the open fishing season, legal-sized lobsters decreased to $36 \%$ at PLS but remained the same (62\%) at WES. The number of sublegal lobsters decreased during the fishing season at both sites during most years, but the decrease was dramatic at PLS in 3 of 5 yr (Fig. 2).

There were more lobsters on forereef and backreef habitats than on patch reefs in both the protected and exploited areas (Fig. 3). The total number of lobsters counted on nearshore patch reefs in WES was high only in 1997, when the total number of juvenile lobsters was high (Fig. 3). The overall percentage of legalsized lobsters increased at WES from nearshore to the forereef: legal-sized lobsters composed $32 \%$ of total

Table 1. Panulirus argus. Mean number of lobsters counted $\mathrm{h}^{-1}$ at Western Sambo Ecological Reserve (WES) and Pelican Shoal (PLS) by year, habitat, and fishing season. nd: no data

\begin{tabular}{|c|c|c|c|c|c|c|c|c|c|}
\hline & & \multicolumn{3}{|c|}{ Closed fishing season } & \multirow[b]{2}{*}{$\begin{array}{c}\text { Nearshore } \\
\text { patch }\end{array}$} & \multicolumn{4}{|c|}{ Open fishing season } \\
\hline & & Forereef & Backreef & $\begin{array}{l}\text { Offshore } \\
\text { patch }\end{array}$ & & Forefeef & Backreef & $\begin{array}{l}\text { Offshore } \\
\text { patch }\end{array}$ & $\begin{array}{c}\text { Nearshore } \\
\text { patch }\end{array}$ \\
\hline \multirow[t]{5}{*}{ WES } & 1997 & 20.67 & 36.00 & 8.22 & 48.05 & 3.00 & 53.11 & 21.67 & 38.58 \\
\hline & 1998 & 19.33 & 15.00 & 12.00 & 21.33 & 8.00 & 28.67 & 34.00 & nd \\
\hline & 1999 & 34.67 & 86.00 & 24.33 & 20.33 & 69.59 & 30.67 & 47.00 & 11.00 \\
\hline & 2000 & 76.57 & 54.67 & 26.33 & 4.95 & 70.67 & 45.67 & 15.33 & 8.67 \\
\hline & 2001 & 56.33 & 30.67 & 6.00 & 4.00 & 42.33 & 26.33 & 23.33 & 6.67 \\
\hline \multirow[t]{5}{*}{ PLS } & 1997 & 45.67 & 27.33 & 19.33 & 19.60 & 11.67 & 10.33 & 4.67 & 6.33 \\
\hline & 1998 & 43.33 & 15.67 & 10.67 & 20.00 & 16.00 & 19.67 & 16.67 & nd \\
\hline & 1999 & 27.33 & 71.33 & 42.67 & 46.67 & 23.00 & 16.33 & 9.00 & 7.00 \\
\hline & 2000 & 52.67 & 13.00 & 27.00 & 21.67 & 17.84 & 12.00 & 5.67 & 3.67 \\
\hline & 2001 & 33.00 & 22.33 & 8.33 & 0.67 & 13.33 & 20.33 & 5.67 & 1.00 \\
\hline
\end{tabular}


lobsters on nearshore patch reefs, $62 \%$ on offshore patch reefs, $64 \%$ on the backreef, and $72 \%$ on the forereef. At the exploited site, however, legal-sized lobsters were $36 \%$ of the lobsters on nearshore patch reefs, $59 \%$ on offshore patch reefs, $41 \%$ on the backreef, and $52 \%$ on the forereef for the 5 yr study period.

Ovigerous female lobsters were found principally in forereef and backreef habitats. At WES during the closed fishing season, the percentage of reproductively active females on the forereef increased immediately from $67 \%$ in July 1997 to $97 \%$ in July 1998, concurrent with the appearance of very large males in the reserve. Since that time, the percentage of reproductively active females (those in possession of ripe ovaries, spermatophores, and/or egg masses) on the forereef has remained at 96 to $97 \%$ during July. The actual number of reproductively active females we observed at WES forereef increased steadily from 22 in 1997 to a high of 120 in 2000. No such trend was observed at the exploited site, where the percentage of reproductive females ranged from 76 to $89 \%$, and the number observed ranged from 34 to 84 .

\section{Sex ratio}

At both sites, protected and exploited, females generally outnumbered males on the forereef regardless of fishing season and on the backreef during the open fishing season (Table 2). On patch reefs, there were usually more males than females during the closed

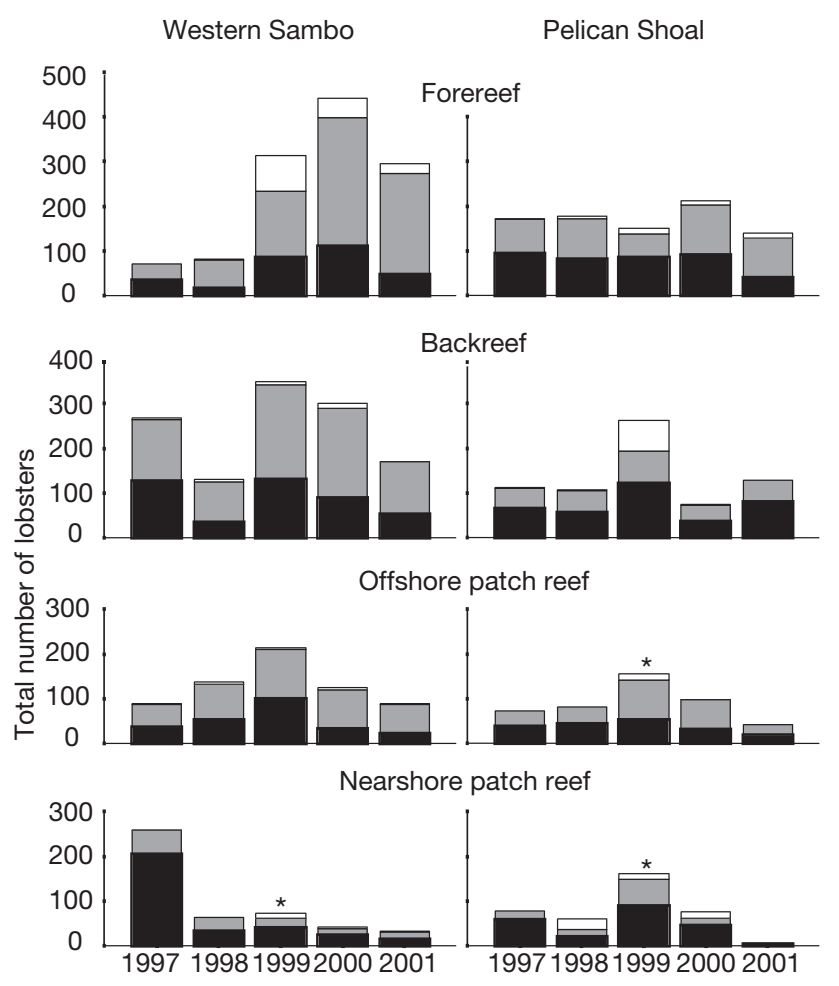

Fig. 3. Panulirus argus. Total number of lobsters (closed + open fishing seasons) counted in Western Sambo Ecological Reserve (WES) and Pelican Shoal (PLS) 1997 to 2001 by habitat. Bars represent the sum of 6 searches (60 min each; 3 replicates $\times 2$ seasons). *: data extrapolated; black bars: sublegalsized lobsters; gray bars: legal-sized lobsters; white bars: lobster size not determined

Table 2. Panulirus argus. Sex ratio (female:male) of lobsters in Western Sambo Ecological Reserve (WES) and Pelican Shoal (PLS) by habitat and fishing season (closed/open). Data are sums of replicate samples in each habitat. Total = all lobsters. Legal $=$ legal-sized lobsters ( $\geq 76 \mathrm{~mm} \mathrm{CL}$ ). nd: no data; nl: no lobsters; nm: no males; nf: no females

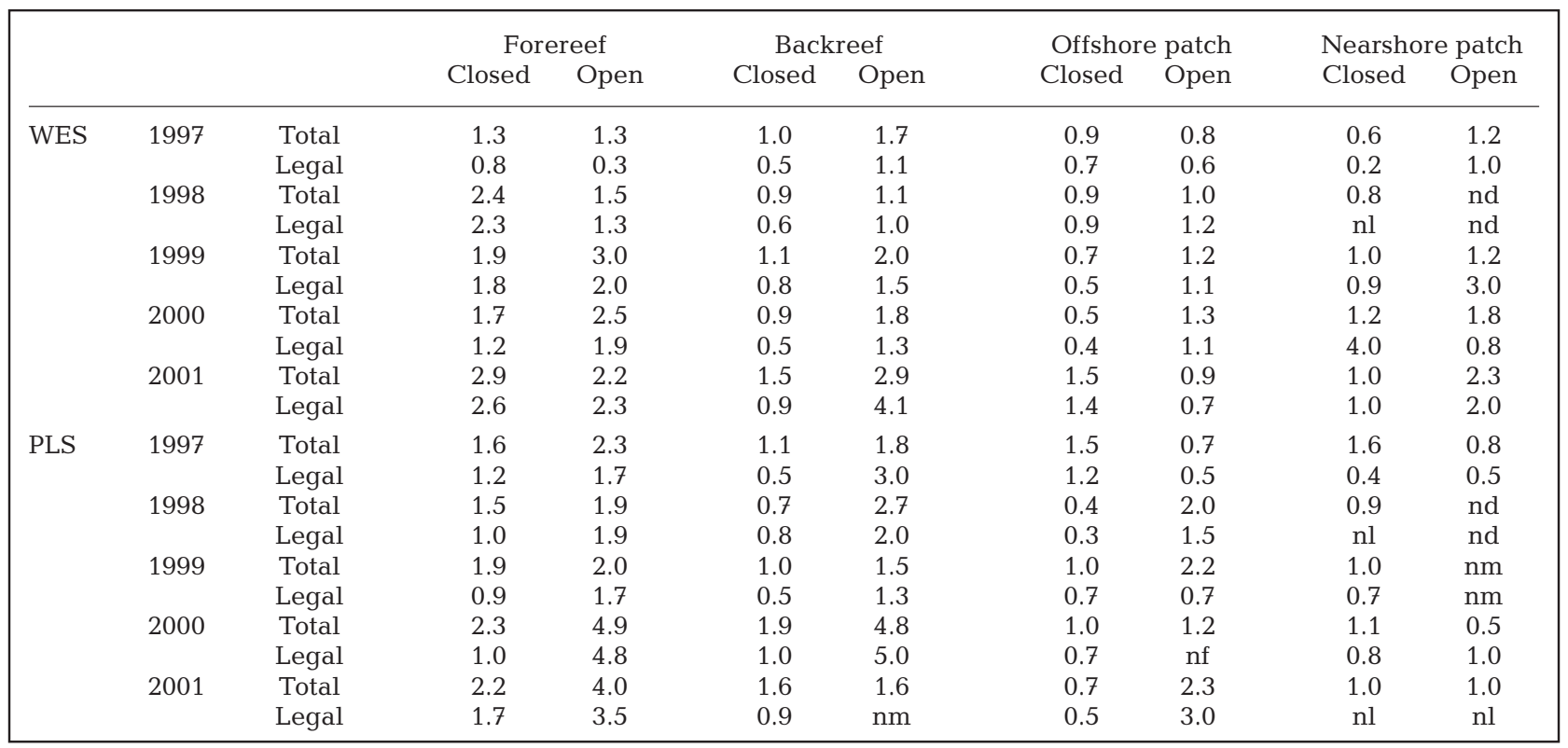


Table 3. Panulirus argus. ANOVA for log-transformed total sex ratio. ${ }^{*}$ denotes difference significant at the 0.05 level

\begin{tabular}{|lcccrc|}
\hline Source of variation & SS & df & MS & $F$ & $p$ \\
\hline Season & 0.37 & 1 & 0.37 & 14.06 & $0.0005^{*}$ \\
Habitat & 1.28 & 3 & 0.43 & 16.16 & $0.0005^{*}$ \\
Season $\times$ Habitat & 0.11 & 3 & 0.04 & 1.38 & 0.255 \\
Error & 1.82 & 69 & 0.02 & & \\
\hline
\end{tabular}

Table 4. Panulirus argus. ANOVA for log-transformed sex ratio of legal-sized lobsters. ${ }^{*}$ denotes difference significant at the 0.05 level

\begin{tabular}{|lccccl|}
\hline Source of variation & SS & df & MS & $F$ & $p$ \\
\hline Season & 0.91 & 1 & 0.91 & 14.63 & $0.008^{*}$ \\
Habitat & 0.81 & 3 & 0.27 & 4.34 & $0.0005^{*}$ \\
Season $\times$ Habitat & 0.31 & 3 & 0.10 & 1.64 & 0.145 \\
Error & 3.93 & 63 & 0.06 & & \\
\hline
\end{tabular}

fishing season and more females than males during the open fishing season. The sex ratio (F:M) of legal-sized lobsters on the backreef shifted strongly toward females from the closed fishing season to the open fishing season every year (Table 2).

Total sex ratio (legal and sublegal-sized lobsters) did not differ between sites, so sites were combined and total sex ratio was analyzed by habitat and fishing season. Sex ratio differed significantly between habitats and by fishing season (closed < open) (Table 2, Table 3). Sex ratio was significantly more skewed toward females on the forereef than elsewhere and was significantly higher on the backreef than on patch reefs (SNK: $\mathrm{p}<0.05$ ).

Analysis of only legal-sized lobsters produced similar statistical results. There was no effect of site, so sites were combined and sex ratio was analyzed by habitat and fishing season. Habitat and fishing season were significant effects on the sex ratio of legal-sized lobsters (Table 2, Table 4). The sex ratio of legal-sized lobsters was significantly higher on forereef and backreef than on patch reefs (SNK: p < 0.05), and sex ratio was significantly higher during the open fishing season than during the closed fishing season. Total sex ratio was consistently higher than the sex ratio of legalsized lobsters at the forereef at both the protected and unprotected sites, regardless of season, indicating a preponderance of sublegal females at the forereef.

\section{Size}

When all lobsters sampled are considered, the size of lobsters collected was extremely variable by site (exploited versus protected), habitat, and fishing sea- son. Homogeneous variance was not obtained by transforming the data. Because the very small size of lobsters from occasional recruitment events increased the size variance and because protection from harvest should be most evident in the fishable population, we report the results of size analyses of only the legalsized lobsters.

The sizes of legal lobsters were compared by site, year, season, and habitat. Season was not a significant factor, so seasons were combined and the sizes of legal lobsters were compared by site, year, and habitat. Site, year, and habitat were significant factors affecting legal lobster size (Table 5). Legal-sized lobsters were significantly larger in the protected area than in the exploited area. Legal lobsters were significantly smaller in 1997 than in subsequent years (T2: p < 0.0005) and significantly larger in 2001 than in all years but 1998 (T2: < 0.0005). There was a significant site-by-habitat interaction associated with the very large lobsters on offshore patch reefs in the reserve. Within WES, the size of legal lobsters varied significantly by year (Table 6, Fig. 4A). Legal-sized lobsters in WES were significantly smaller in 1997 than in subsequent years (T2: $\mathrm{p}<0.0005)$, and significantly larger in 2001 than in 2000 (T2: $p=0.010$ ). Year was not a significant factor for PLS (Table 6, Fig. 4A). In the reserve, legal lobsters were significantly larger on offshore patches than all other habitats (T2: $p<0.0005)$. In PLS, offshore patch reef lobsters were larger than only those on the backreef (T2: $\mathrm{p}<0.0005)$.

The largest lobsters, both male and female, were found at offshore patch reefs (Fig. 4B,C), and there has been an increase in the frequency of large $(\geq 100 \mathrm{~mm}$ CL) lobsters, particularly males, within WES since 1997. No large ( $\geq 100 \mathrm{~mm} C L)$ females were present in our samples at either site until 1999. Beginning in 1999, large females comprised 1 to $2 \%$ of the legal lobsters (16 lobsters in $3 \mathrm{yr}$ ) at the protected site, but we found only 2 large females at the exploited site during 5 yr of sampling. In 1997, large male lobsters $(\geq 100 \mathrm{~mm}$ CL) comprised only $1 \%$ of legal-sized WES lobsters; they were absent from the exploited site, PLS (Fig. 5). Since that time, large males have comprised 7 to $9 \%$ of legal lobsters in the reserve each year, but only 2 to $3 \%$ of the legal lobsters at Pelican Shoal.

\section{Abundance}

Lobster abundance (relative abundance $=$ mean number of lobsters observed in $1 \mathrm{~h}$ ) generally followed similar patterns at both the protected and exploited sites, with the major differences resulting from fishing mortality of legal-sized lobsters at the exploited site during the fishing season (Fig. 6). One notable differ- 
Table 5. Panulirus argus. ANOVA for size of legal-sized lobsters. *denotes difference significant at the 0.05 level

\begin{tabular}{|lrcrrl|}
\hline Source of variation & SS & df & MS & $F$ & p \\
\hline Site & 2157.06 & 1 & 2157.06 & 38.02 & $0.0005^{*}$ \\
Year & 1013.19 & 4 & 253.30 & 4.47 & $0.001^{*}$ \\
Habitat & 4493.27 & 3 & 1497.76 & 26.40 & $0.0005^{*}$ \\
Site $\times$ Year & 396.46 & 4 & 99.11 & 1.75 & 0.137 \\
Site $\times$ Habitat & 1152.53 & 3 & 3384.18 & 6.77 & $0.0005^{*}$ \\
Year $\times$ Habitat & 1041.98 & 12 & 86.83 & 1.53 & 0.106 \\
Site $\times$ Year $\times$ Habitat & 738.31 & 12 & 61.53 & 1.09 & 0.368 \\
Error & 171093.52 & 3016 & 56.73 & & \\
\hline
\end{tabular}

Table 6. Panulirus argus. ANOVA for size of legal-sized lobsters by site (WES, PLS). *denotes difference significant at the 0.05 level

\begin{tabular}{|c|c|c|c|c|c|c|}
\hline \multicolumn{2}{|c|}{ Source of variation } & \multirow{2}{*}{$\begin{array}{c}\text { SS } \\
2766.43\end{array}$} & \multirow{2}{*}{$\frac{\mathrm{df}}{4}$} & \multirow{2}{*}{$\begin{array}{c}\text { MS } \\
691.61\end{array}$} & \multirow{2}{*}{$\begin{array}{c}F \\
10.27\end{array}$} & \multirow{2}{*}{$\frac{p}{0.0005^{*}}$} \\
\hline WES & Year & & & & & \\
\hline & Habitat & 6667.93 & 3 & 2222.64 & 32.99 & $0.0005^{*}$ \\
\hline & Year $\times$ Habitat & 1329.52 & 12 & 110.79 & 1.65 & 0.073 \\
\hline & Error & 134729.28 & 2000 & 67.37 & & \\
\hline \multirow[t]{4}{*}{ PLS } & Year & 174.88 & 4 & 43.72 & 1.22 & 0.300 \\
\hline & Habitat & 642.67 & 3 & 214.22 & 5.99 & $0.0005^{*}$ \\
\hline & Year $\times$ Habitat & 721.78 & 12 & 60.15 & 1.68 & 0.066 \\
\hline & Error & 36364.24 & 1016 & 35.79 & & \\
\hline
\end{tabular}

ence, however, was that abundance of lobsters (both total and legal) on patch reefs in the reserve usually increased from the closed to the open fishing seasons; the pattern was reversed at the exploited site. Year was never a significant factor influencing total or legal lobster abundance. For this reason, years were combined for subsequent analyses reported herein.

Total lobster abundance varied significantly by site, season, and habitat (Table 7). The forereef and backreef housed significantly more lobsters than the patch reefs (Table 7; T2: p < 0.05). There was a significant site-by-season interaction resulting from the greater reduction in lobster abundance at PLS than WES during the fishing season that precluded conclusions about the main effects of site and season, so sites were analyzed separately. When abundance was analyzed by site, habitat was not a significant factor affecting total lobster abundance at PLS, but season was significant (ANOVA: $F=18.07$, $\mathrm{df}=1,106, \mathrm{p}<0.0005)$. Season was not
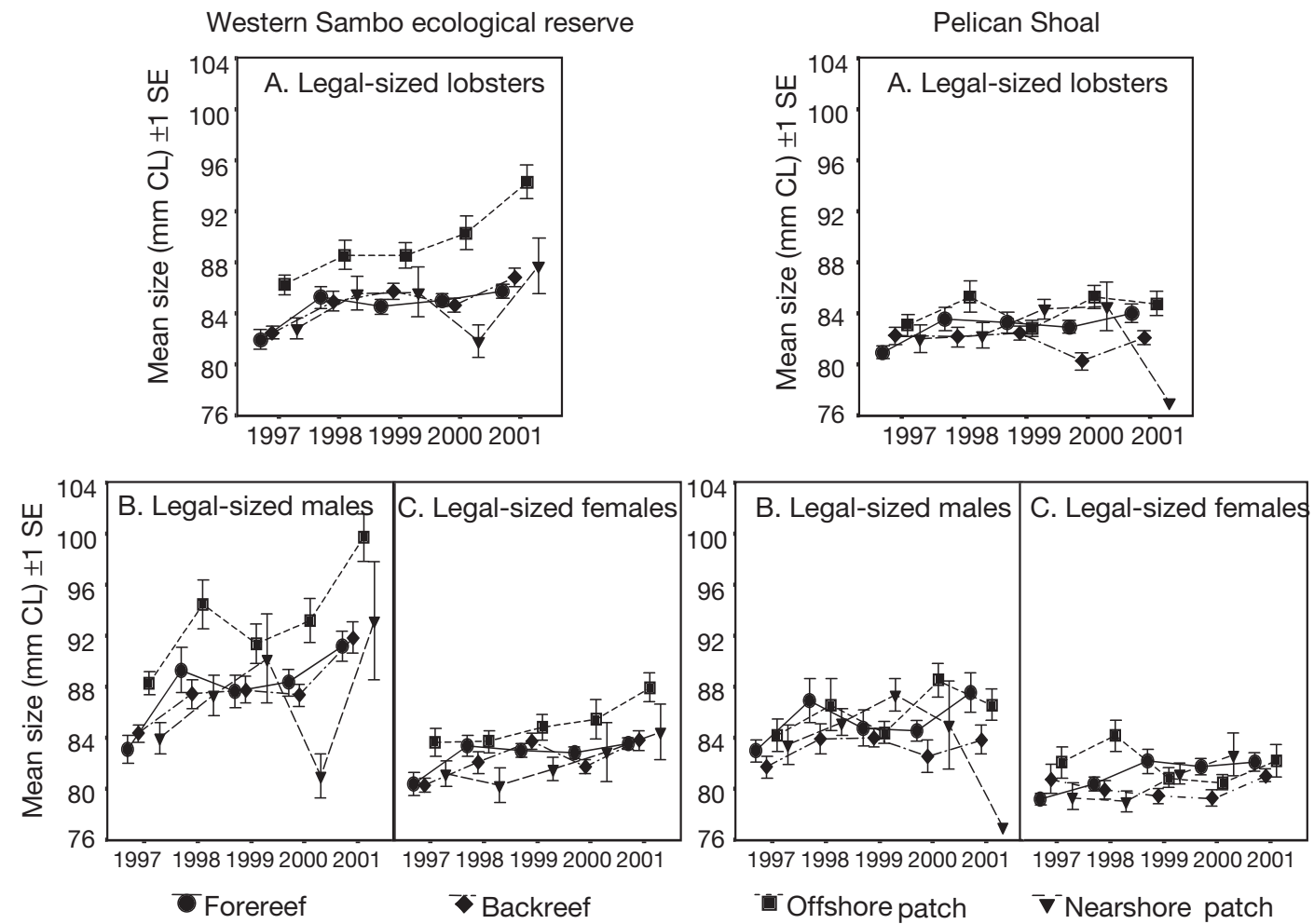

Fig. 4. Panulirus argus. Mean size ( $\pm 1 \mathrm{SE}$ ) of legal-sized lobsters in Western Sambo Ecological Reserve (WES) and Pelican Shoal (PLS) 1997 to 2001 by (A) habitat and by $(\mathrm{B}, \mathrm{C})$ habitat with sexes separated 


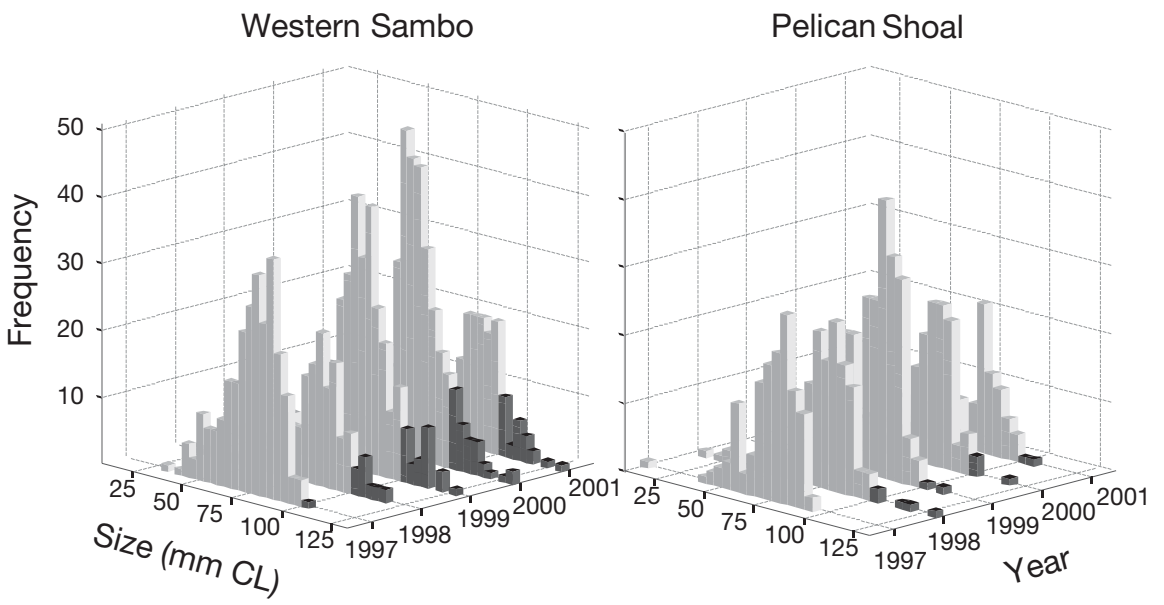

Fig. 5. Panulirus argus. Size-frequency of male spiny lobsters at Western Sambo Ecological Reserve (WES) and Pelican Shoal (PLS) from 1997 to 2001. Data are from all habitats combined. Large males ( $\geq 100 \mathrm{~mm} \mathrm{CL}$ ) are depicted by dark bars. Note the increased frequency of large males in the reserve since 1997

Table 7. Panulirus argus. ANOVA for total lobster abundance. * denotes difference significant at the 0.05 level

\begin{tabular}{|lrcccc|}
\hline Source of variation & SS & df & MS & $F$ & p \\
\hline Site & 6229.02 & 1 & 6229.02 & 8.33 & $0.004^{*}$ \\
Season & 4208.87 & 1 & 4208.87 & 5.63 & $0.019^{*}$ \\
Habitat & 14554.92 & 3 & 4851.64 & 6.49 & $<0.0005^{*}$ \\
Site $\times$ Season & 4222.63 & 1 & 4222.63 & 5.65 & $0.018^{*}$ \\
Site $\times$ Habitat & 1303.14 & 3 & 434.38 & 0.58 & 0.628 \\
Season $\times$ Habitat & 1489.51 & 3 & 496.50 & 0.66 & 0.575 \\
Site $\times$ Season $\times$ Habitat & 790.07 & 3 & 263.36 & 0.35 & 0.788 \\
Error & 159300.21 & 213 & 747.89 & & \\
\hline
\end{tabular}

Table 8. Panulirus argus. ANOVA for abundance of legal-sized lobsters. ${ }^{*}$ denotes difference significant at the 0.05 level

\begin{tabular}{|lrcrrr|}
\hline Source of variation & SS & df & MS & $F$ & $p$ \\
\hline Site & 4155.17 & 1 & 4155.17 & 18.04 & $<0.0005^{*}$ \\
Season & 1531.40 & 1 & 1531.40 & 6.65 & $0.011^{*}$ \\
Habitat & 7159.39 & 3 & 2386.46 & 10.36 & $<0.0005^{*}$ \\
Site $\times$ Season & 1189.13 & 1 & 189.13 & 5.16 & $0.024^{*}$ \\
Site $\times$ Habitat & 1941.64 & 3 & 647.21 & 2.81 & $0.040^{*}$ \\
Season $\times$ Habitat & 408.45 & 3 & 136.15 & 0.59 & 0.621 \\
Site $\times$ Season $\times$ Habitat & 631.25 & 3 & 210.42 & 0.91 & 0.435 \\
Error & 49057.75 & 213 & 230.32 & & \\
\hline
\end{tabular}

Table 9. Panulirus argus. ANOVA for abundance of legal-sized lobsters by site (WES, PLS). ${ }^{*}$ denotes difference significant at the 0.05 level

\begin{tabular}{|llrrrrc|}
\hline Source of variation & SS & df & MS & $F$ & $p$ \\
\hline WES & Season & 10.85 & 1 & 10.85 & 0.03 & 0.860 \\
& Habitat & 7670.17 & 3 & 2556.72 & 7.41 & $<0.0005^{*}$ \\
& Season $\times$ Habitat & 625.86 & 3 & 208.62 & 0.60 & 0.61 \\
& Error & 36945.00 & 107 & 345.28 & & \\
PLS & 2698.43 & 1 & 2698.43 & 23.61 & $<0.0005^{*}$ \\
& Season & 1442.85 & 3 & 480.95 & 4.21 & 0.007 \\
& Habitat & 42.89 & 3 & 140.30 & 1.23 & 0.303 \\
& Season $\times$ Habitat & 12112.75 & 106 & 114.27 & & \\
Error & & & & & \\
\hline
\end{tabular}

significant at WES; however, habitat was a significant factor (ANOVA: $F=$ 3.75, df =3,107, $\mathrm{p}<0.013$ ). Total lobster abundance was significantly higher on the backreef than on inshore patch reefs (T2: $\mathrm{p}=0.04)$.

Legal-sized lobster abundance fluctuated similarly to total lobster abundance. There was a significant site effect, with more legals in the reserve than in the exploited area; a significant fishing season effect, with greater legal lobster abundance during the closed fishing season; and a significant habitat effect (Table 8, Fig. 6). Legalsized lobsters were significantly less abundant on nearshore patch reefs than elsewhere (T2: $p<0.01)$. There were significant site-by-fishing season and site-by-habitat interactions (Table 8), so sites were analyzed separately. Legal-sized lobster abundance was similar during both fishing seasons in the reserve, but in the exploited area, there was a significant reduction of legal-sized lobsters during the open fishing season (Table 9). In the reserve, there was a significant habitat effect, with significantly more legal lobsters on forereef than nearshore patch reefs and significantly fewer legal-sized lobsters on nearshore patch reefs than elsewhere (T2: $\mathrm{p}<0.05$ ) (Fig. 6). There was also a significant habitat effect within the exploited area, with significantly fewer legal-sized lobsters on nearshore patch reefs than elsewhere (T2: p < 0.05) (Table 9, Fig. 6). 

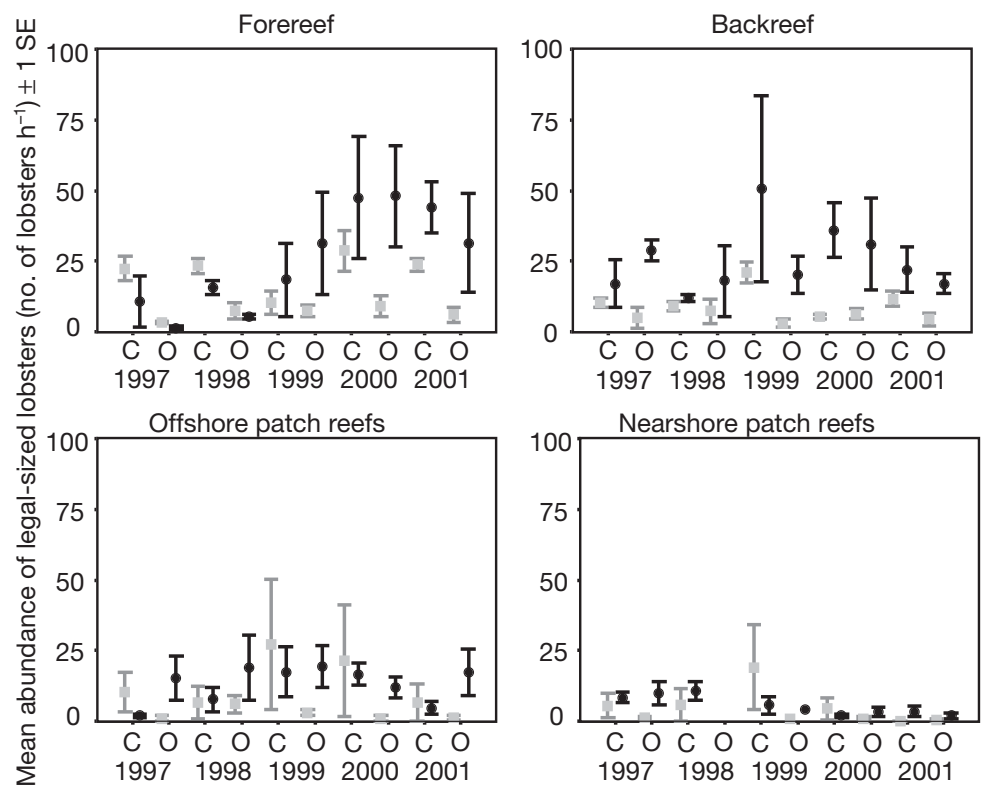

Fig. 6. Panulirus argus. Abundance of legal-sized lobsters in Western Sambo Ecological Reserve (WES) and Pelican Shoal (PLS) from 1997 to 2001 by habitat and fishing season (C: closed; O: open). Data presented are means of 3 replicate samples. Gray: PLS (exploited area); black: WES (protected area)

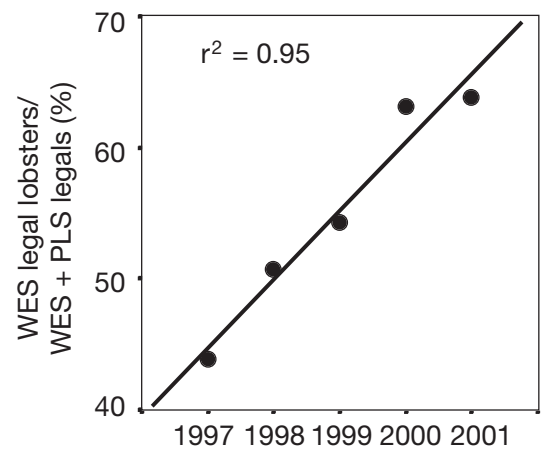

Fig. 7. Panulirus argus. Legal-sized lobsters in Western Sambo Ecological Reserve (WES) during the closed fishing season 1997 to 2001 expressed as a percentage of all legalsized lobsters counted in WES and Pelican Shoal (PLS)

The abundance of legal-sized lobsters in WES during the closed fishing season has increased significantly as a percentage of all legal-sized lobsters sampled $\left(\mathrm{r}^{2}=0.95\right.$, $F=63.6, \mathrm{p}=0.004)$. In July 1997, $44 \%$ of all legal-sized lobsters sampled were found in WES. By 2001, WES housed $61 \%$ of all legal-sized lobsters sampled (Fig. 7).

\section{DISCUSSION}

Understanding movement patterns of Panulirus argus is essential in evaluating efficacy of marine reserves for this species. Large-scale ontogenic habitat shifts and reproductive migrations of spiny lobsters are well documented (Herrnkind et al. 1975, Kanciruk 1980, Childress \& Herrnkind 1994). WES may protect some lobsters throughout their ontogeny by providing a protected corridor that extends from juvenile habitat on nearshore patch reefs to adult reproductive habitat on the forereef. The likelihood that an individual would remain within the arbitrary boundaries of the reserve from settlement through adulthood is low, however. More importantly, habitat for spiny lobsters in all lifestages is protected within the reserve.

It is apparent that some spiny lobsters stay within a home range for extended periods of time, despite their ability to migrate long distances. During a 6 mo study, Herrnkind et al. (1975) found 3 distinct types of lobsters at their sites in St. John, US Virgin Islands: (1) longterm residents - those present continually for several months or intermittently over many months; (2) new residents - new recruits from nursery areas or immigrants that establish residency; and (3) transients. Hunt et al. (1991) found that $4 \%$ of tagged lobsters were resident in the 50 ha protected core area at Looe Key National Marine Sanctuary (now Looe Key SPA) for 9 to 12 mo, and $3 \%$ were resident for more than 12 mo. Among the longterm residents were a large male $(110 \mathrm{~mm} \mathrm{CL})$ and a large female (102 mm CL), which were recaptured repeatedly from the same site for 8 mo. Most lobsters, however, were either never resighted or were resighted for only a few weeks before disappearing from the study area. Based on their observations, Hunt et al. (1991) speculated that a residential population might be developing even in a protected area as small as Looe Key. In contrast, residency of large lobsters has been documented in the Dry Tortugas National Park lobster reserve, where $94 \%$ of recaptures were made near the release location, some as long as 2 yr after initial release (Davis 1977).

Our data indicate that many lobsters have become resident in WES. The majority of the lobsters in WES are larger than the legal-size limit, in contrast to those at the exploited site. If the shift of the size composition of catch toward an increasing proportion of smaller lobsters is one indication of fishing pressure (Lyons et al. 1981), the reverse should also be true. An increasing proportion of larger lobsters in an area indicates release from fishing pressure. Such an increase was seen in the reserve, but not in the exploited area (Fig. 2). There also has been an increase in the frequency of large lobsters, particularly males, inside the 
reserve that has not been observed at the exploited site (Fig. 5). This increase in male size-frequency suggests that some lobsters remain inside the reserve for an extended period of time.

There is independent confirmation of some longterm retention of legal-sized lobsters within WES. In June 2001, Gregory (2001b) recaptured a tagged legalsized lobster near the location where it was initially released in WES 19 mo earlier. Though this lobster may have departed and reentered the reserve, it would likely have been captured in the fishery had it left the reserve during the open fishing season. Ongoing sonic tagging of lobsters along the reserve boundary will help us quantify the balance between long-term lobster residency within the reserve and transient lobsters.

Once adults establish residence in WES, the reserve is sufficiently large to protect a portion of them as they travel to foraging grounds and between winter dens and spring spawning habitat. We sampled 12 smaller protected areas (34 to 515 ha) concurrently with sampling WES and did not observe an increase in lobster abundance or mean size or any expansion of size range at any of the smaller protected areas including Looe Key (available at: http://www.fknms.nos.noaa.gov/ research_monitoring/2001_sci_rept.pdf). This is likely because the probability of a lobster wandering out of a small protected area during its daily life is high. Additionally, most of the small protected areas encompass only a single habitat type.

Small-scale movements and detailed habitat usage patterns are not well documented for Panulirus argus; however, understanding these movements is of critical importance in evaluating reserve success. Emigration from WES is evidenced in our data by the reduction in number of lobsters observed in WES between some sampling periods (Fig. 2). Replenishment of lobsters at PLS may, in part, come from WES emigrants. The appearance of a small number of very large males at PLS several years after establishment of WES is an indication that this may be occurring (Fig. 5). Gregory (2001a) also documented migration of lobsters from WES to the fishery. We are currently conducting both mark-recapture and sonic tagging studies to quantify lobster movements inside the reserve, and movement between the reserve and the fishery. Additional replenishment of lobsters at both the reserve and exploited site may result from an influx of new recruits from other areas.

Sublegal lobsters, though not legally harvested, are affected by the recreational and commercial lobster fisheries. Many sublegal lobsters lose legs and antennae to recreational fishers and may be displaced out of the area following harassment (Blonder et al. 1992). Commercial lobster fishers place sublegal lobsters (known as 'shorts') in traps to act as bait (Hunt et al. 1986, Hunt 1994). Many of these 'shorts' die from predation or starvation in traps (Hunt et al. 1986, Hunt 1994) or are transported out of their original capture location. Such loss of sublegal lobsters from the exploited site during the open fishing season was evidenced by a dramatic drop in the number of sublegal lobsters in 3 of the 5 yr sampled.

It is apparent from our data that the lobsters in WES have benefitted from harvest protection. Harvest of lobsters, especially of legal-sized lobsters, from the exploited area is evidenced by the consistent, significant decrease in the number of lobsters counted during the fishing season each year, something that is not evident in the protected area (Fig. 2). Prior to 2000, lobsters appeared to become redistributed between sites in such a way that by each July (closed season), the total number of lobsters counted was similar in the protected and exploited sites (Fig. 2). Stock replenishment in the exploited area most probably results from migrants out of the reserve in addition to new recruits to the fishery that have migrated from nursery areas. Emigration from the reserve is obvious in the data. For example, in the closed seasons of 1998 and 2001, there were far fewer lobsters in the reserve than the previous year (Fig. 2). The redistribution of lobsters out of the reserve and into the fishery suggests that transient lobsters receive refuge from harvest only temporarily - at the beginning of the fishing season. However temporary, this refuge may be of critical importance, because the majority of fishing effort and landings in the lobster fishery occur during the first few months (Hunt 1994, Hunt et al. 1991, 1999). Lobsters that avoid harvest in one season are free to grow and reproduce at least until the following fishing season begins.

The reproductive season for spiny lobsters in Florida lasts from March through September. During this time, there is a general seaward migration from settlement and nursery areas in nearshore habitats to offshore areas for reproduction (Gregory \& Labisky 1986). Larger females spawn earlier in the season and carry exponentially more eggs than do smaller females (Bertelsen \& Cox 2001). Individual females can spawn several times per season, and harvest of ovigerous females is prohibited by law. The effect of this protection is evident in the larger increase in ratio of females to males at PLS than at WES on the forereef during the open fishing season (Table 2). This indicates the differential removal of males from PLS forereef. The fishing season comes at the end of the reproductive season, so the reduction in male abundance may result both from harvest and from emigration. Based on sex ratios (Table 2) and abundance, it appears that some male lobsters leave the forereef after the reproductive season and return to offshore patch reefs, where they are 
caught in PLS but are protected in WES. We attribute the consistent increase in the ratio of females to males between fishing seasons at the backreef habitat (Table 2) to natural movement of males relating to reproduction and not solely to their removal by the fishery, because it occurred at the protected site as well as the exploited site, and the increased sex ratio was attributable to both relative and actual increases in female abundance.

The increased frequency of large male lobsters has important implications in the fecundity of WES lobsters. Females preferentially mate with large males, and clutch size is more strongly correlated with male size than female size (MacDiarmid \& Butler 1999). Bertelsen \& Cox (2001) postulated that the low percentage of female egg bearers in the exploited areas of FKNMS may be due to the relative rarity of large males. As soon as larger males became available for mating in WES, the number of females on the forereef involved in reproduction increased by $30 \%$, and the absolute number increased even more. The increase in ovigerous female abundance has 2-fold benefits. First, ovigerous females are protected from harvest even if they leave the boundaries of the reserve. Second, the greater the number of ovigerous females, the greater the population fecundity. Though recruitment of locally spawned larvae to the ecological reserve is unlikely, the entire pan Caribbean population is interconnected and local populations may be connected via intermediate populations in western Africa or the Caribbean (Silberman et al. 1994, Lee \& Williams 1999). Even if larvae spawned in Florida are not recruited there, they may be important to downstream populations, such as that in Bermuda.

Each year, lobsters harvested in Florida are almost exclusively new recruits to the fishery (Powers \& Sutherland 1989). Landings fluctuate on a 4 to $5 \mathrm{yr}$ cycle (Hunt 1994), and increased landings such as those seen in the mid-1990s result from increased lobster abundance (Muller et al. 1997). With this underlying cyclical variation in lobster abundance, it is not surprising that we were unable to detect a significant increase in lobster abundance in the reserve over time. A significant yearly increase in lobster abundance at any location would be detectable only if immigration always exceeded emigration. This was not the case at either of our study sites. However, the abundance of legal-sized lobsters in WES during the closed fishing season increased significantly relative to PLS during the 5 yr of this study (Fig. 7).

There is evidence that in the first $5 \mathrm{yr}$ of protection, the lobsters in WES are benefitting from protection. Although abundance fluctuates with yearly recruitment, it appears that some lobsters are taking up residence in the reserve. Abundance of legal-sized lob- sters in WES as a percentage of total legal-sized catch in WES and PLS increased significantly over the course of this study. Individuals resident in WES are growing to much larger sizes than lobsters in the exploited area are. The few very large lobsters we have observed in the exploited area may be 'spillover' of biomass, emigrating from the protected area.

The observed patterns of increased lobster abundance, the recent increase in the frequency of large lobsters, and the expansion of the size-range of spiny lobsters in WES all indicate that the reserve provides at least a short-term harvest refuge. Very large lobsters in the reserve may tend to stay in the reserve, because large lobsters display more site fidelity than smaller ones (Little 1972, Davis 1977). Eventually, the local population in WES may display size structure, abundance, and behavioral characteristics of a natural, unexploited adult spiny lobster population.

Acknowledgements. Funding for this study was provided in part by the National Oceanographic and Atmospheric Administration under purchase orders 7-WC-A-90005, 43WC-NC-900917，40-WC-NA-006223 and 40WCNA1A0341. The views expressed herein are those of the authors and do not necessarily reflect the views of NOAA or any of its subagencies. Special thanks are due to the numerous scientific divers who assisted with data collection at these and other reserve sites: C. Adams, R. Bertelsen, D. Bryan, C. Cummings, M. Darcy, S. Donahue, J. Dulberger, D. Eaken, A. Fleeting, J. Ford, D. Gregory, T. Hamilton, B. Haskell, D. Hawtof, N. Jue, J. Kidney, T. Matthews, K. Maxwell, A. McCarthy, K. O'Brien, J. Parker, R. Poretsky, B. Richards, D. Robertson, B. Sharp, G. Stoecklin, N. Strattman, E. Tynes, and T. Williams (lobster team), and A. Acosta, L. Anderson, C. Bartels, J. Colvocoresses, G. Delgado, J. Dotten, T. Dunmire, D. Eggleston, B. Glazer, K. Haddad, C. Humphreys, M. Johnson, E. Kadison, K. McCarthy, P. O'Donnell, J. O'Hop, B. Payne, D. Snodgrass, J. Styer (support divers). We are indebted to J. Leiby, J. Quinn, and L. French for their editorial expertise. Critical review of various iterations of this manuscript was provided by B. Keller, A. McMillenJackson, R. Muller, and 4 anonymous reviewers.

\section{LITERATURE CITED}

Acosta CA (2001) Assessment of the functional effects of a harvest refuge on spiny lobster and queen conch populations at Glover's Reef, Belize. Proc 52nd Gulf Carib Fish Inst 2:212-221

Acosta CA (2002) Spatially explicit dispersal dynamics and equilibrium population sizes in marine harvest refuges. J Mar Sci 59:458-468

Beaver RW (2000) Fishery-dependent monitoring in the Florida Keys: a summary of twelve years of data. Proc 51st Gulf Carib Fish Inst 51:271-282

Bertelsen RD, Cox C (2001) Sanctuary roles in population and reproductive dynamics of Caribbean spiny lobster. In: Kruse GH, Bez N, Booth A, Dorn MA and 6 others (eds) Spatial processes and management of marine populations. University of Alaska Sea Grant College Program, AK-SG01-02, Fairbanks, AK, p 591-605 
Bertelsen RD, Hunt JH (1991) Results of the 1991 mail surveys of recreational lobster fishermen (special sport season and regular season surveys). Report to the Florida Marine Fisheries Commission. Florida Marine Research Institute, Marathon, FL

Bertelsen RD, Hunt JH, Muller R (2000) Spiny lobster spawning potential and population assessment: a monitoring program for the south Florida fishing region. Report to National Marine Fisheries Service MARFIN Grant 0518-96-99. Florida Marine Research Institute, Marathon, FL

Blonder BI, Hunt JH, Forcucci D, Lyons WG (1992) Effects of recreational and commercial fishing on spiny lobster abundance at Looe Key National Marine Sanctuary. Proc 41st Gulf Carib Fish Inst 41:487-491

Bohnsack JA (1996) Marine reserves, zoning, and the future of fishery management. Fisheries 21:14-16

Childress MJ (1997) Marine reserves and their effects on lobster populations: report from a workshop. Mar Freshw Res 8:111-114

Childress MJ, Herrnkind WF (1994) The behavior of juvenile Caribbean spiny lobster in Florida Bay: seasonality, ontogeny, and sociality. Bull Mar Sci 54:819-827

Cox C, Hunt JH, Lyons WG, Davis GE (1997) Nocturnal foraging of the Caribbean spiny lobster, Panulirus argus, at offshore reefs of Florida, USA. Mar Freshw Res 48:671-680

Davis GE (1975) Minimum size of mature spiny lobsters, Panulirus argus, at Dry Tortugas, Florida. Trans Am Fish Soc 104:675-676

Davis GE (1977) Effects of recreational harvest on a spiny lobster, Panulirus argus, population. Bull Mar Sci 27:223-236

Davis GE, Dodrill JW (1980) Marine parks and sanctuaries for spiny lobster fisheries management. Proc 32nd Gulf Carib Fish Inst 32:194-207

Davis GE, Dodrill JW (1989) Recreational fishery and population dynamics of spiny lobsters, Panulirus argus, in Florida Bay, Everglades National Park. Bull Mar Sci 44(1):78-88

DOC (US Department of Commerce) (1996) Florida Keys National Marine Sanctuary final management plan/environmental impact statement (FMP/EIS). Vol 1. National Oceanic and Atmospheric Administration (NOAA), Silver Spring, MD

Gregory DR Jr (2001a) Sentinel lobster fisheries project for the Florida Keys National Marine Sanctuary, January to December 2000. 2000 Annual report to the Florida Keys National Marine Sanctuary. University of Florida/Monroe County Cooperative Extension Services, Key West, FL

Gregory DR Jr (2001b) Sentinel lobster fisheries project for the Florida Keys National Marine Sanctuary, January to June 2001. 2001 Semi-annual report to the Florida Keys National Marine Sanctuary. University of Florida/Monroe County Cooperative Extension Services, Key West, FL

Gregory DR Jr, Labisky RF (1986) Movements of the spiny lobster Panulirus argus in south Florida. Can J Fish Aquat Sci 43:2228-2234

Harper DE (1995) The 1995 spiny lobster update of trends in landings, CPUE, and size of harvested lobster. MIA94/95-47. National Oceanic and Atmospheric Association/National Marine Fisheries Service, Miami, FL

Harper D, Muller R (2001) Spiny lobster fisheries of the United States of America. In: FAO/Western Central Atlantic Fishery Commission. Report on the FAO/DANIDA/ CFRAMP/WECAFC regional workshops on the assessment of the Caribbean spiny lobster (Panulirus argus). Belize City, Belize 21 Apr to 2 May 1997 and Merida, Yucatan, Mexico, 1 to 12 Jun 1998. FAO Fisheries Report No. 619. FAO, Rome, p 258-278
Herrnkind WF, VanDerwalker JA, Barr L (1975) Population dynamics, ecology and behavior of spiny lobsters, Panulirus argus, of St. John, US Virgin Islands: (IV) Habitation, patterns of movement and general behavior. Results of the Tektite Program. Science Bulletin, Natural History Museum of Los Angeles County 20:31-45

Hunt JH (1994) Status of the fishery for Panulirus argus in Florida. In: Phillips BF, Cobb JS, Kittaka J (eds) Spiny lobster management. Blackwell Scientific, Oxford, p 158-168

Hunt JH, Lyons WG, Kennedy FS Jr (1986) Effects of exposure and confinement on spiny lobsters, Panulirus argus, used as attractants in the Florida trap fishery. Fish Bull 84: $69-76$

Hunt JH, Matthews TR, Forcucci D, Hedin B, Bertelsen RD (1991) Management implications of trends in the population dynamics of the Caribbean spiny lobster, Panulirus argus, at Looe Key National Marine Sanctuary. Final Report to NOAA. Florida Marine Research Institute, Marathon, FL

Hunt JH, Sharp WC, Matthews TR, Muller RG, Bertelsen RD, Cox C (1999) Status of the spiny lobster fishery in Florida, 1999. Report to the Florida Fish \& Wildlife Conservation Commission. Florida Marine Research Institute, Marathon, FL

Kanciruk P (1980) Ecology of juvenile and adult Palinuridae (spiny lobsters). In: Cobb S, Phillips B (eds) The biology and management of lobsters, Vol 2. Academic Press, New York, p 59-96

Kelly S, Scott D, MacDiarmid AB, Babcock RC (2000) Spiny lobster, Jasus edwardsii, recovery in New Zealand marine reserves. Biol Conserv 92:359-369

Lee TN, Williams E (1999) Mean distribution and seasonal variability of coastal currents and temperature in the Florida Keys with implications for larval recruitment. Bull Mar Sci 64:35-56

Little EJ Jr (1972) Tagging of spiny lobsters (Panulirus argus) in the Florida Keys, 1967-1969. Fla Dep Nat Res Spec Sci Rep No 31. Florida Department of Natural Resources, St. Petersburg, FL

Lipcuis RN, Stockhausen WT, Eggleston DB (2001) Marine reserves for Caribbean spiny lobster: empirical evaluation and theoretical metapopulation recruitment dynamics. Mar Freshw Res 52:1589-1598

Lyons WG, Dean GB, Foster SM, Kennedy FS Jr, Milano GR (1981) The spiny lobster, Panulirus argus, in the middle and upper Florida Keys: population structure, seasonal dynamics, and reproduction. Fla Mar Res Inst Publ. No 38. Florida Department of Natural Resources, Marine Research Laboratory, St. Petersburg, FL

MacDiarmid AB (1991) Seasonal changes in depth, distribution, sex ratio and size frequency of spiny lobster Jasus edwardsii on a coastal reef in northern New Zealand. Mar Ecol Prog Ser 70:129-141

MacDiarmid AB, Breen PA (1993) Spiny lobster population change in a marine reserve. In: Battershill CN, Creese $\mathrm{R}$, Schiel D, Jones G, MacDiarmid AB (eds) Proceedings of the 2nd International Temperate Reef Symposium. National Institute of Water and Atmospheric Research, Wellington, p 47-56

MacDiarmid AB, Butler MJ IV (1999) Sperm economy and limitation in spiny lobsters. Behav Ecol Sociobiol 46: $14-24$

MacDiarmid AB, Hickey B, Maller RA (1991) Daily movement patterns of the spiny lobster Jasus edwardsii (Hutton) on a shallow reef in northern New Zealand. J Exp Mar Biol Ecol 147:185-205 
Muller RG, Hunt JH, Matthews TR, Sharp WC (1997) Evaluation of effort reduction in the Florida Keys spiny lobster, Panulirus argus, fishery using an age-structured population analysis. Mar Freshw Res 48:1045-1058

Odum EP (1971) Fundamentals of Ecology, 3rd edn. Saunders College Publishing, Philadelphia, PA

Powers JE, Sutherland DL (1989) Spiny lobster assessment. CPUE, size frequency, yield per recruit, and escape gap analyses. NOAA/NMFS/SFC/CRD-88/89-24. National Marine Fisheries Service, Miami, FL

Schmitt EF, Sluka RD, Sullivan-Sealey KM (2002) Evaluating the use of roving diver and transect surveys to assess the coral reef fish assemblage off southeast Hispaniola. Coral Reefs 21:216-223

Schonewald-Cox CM, Bayless JW (1986) The boundary model: a geographical analysis of design and conservation

Editorial responsibility: Kenneth Sherman (Contributing Editor), Narragansett, Rhode Island, USA of nature reserves. Biol Conserv 38:305-322

Sharp WC, Bertelsen RD, Hunt JH (2004) The 1994 Florida recreational spiny lobster fishing season: results of a mail survey. Proc 48th Gulf Carib Fish Inst 48:93-110

Silberman JD, Sarver SK, Walsh PJ (1994) Mitochondrial DNA variation and population structure in the spiny lobster Panulirus argus. Mar Biol 120:601-608

Sladek Nowlis J, Roberts CM (1999) Fishery benefits and optimal design of marine reserves. Fish Bull 97:604-616

SPSS (1999) SPSS Advanced Models ${ }^{\mathrm{TM}}$ 9.0. SPSS, Chicago, IL

Warner RE, Combs CL, Gregory DR Jr (1977) Biological studies of the spiny lobster, Panulirus argus (Decapoda: Palinuridae) in south Florida. Proc 29th Gulf Carib Fish Inst 29:166-183

Zar HJ (1984) Biostatistical Analysis. Prentice-Hall, Englewood Cliffs, NJ

Submitted: September 23, 2003; Accepted: November 8, 2004 Proofs received from author(s): May 25, 2005 